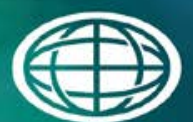

Savannah River

National Laboratory ${ }^{m}$

OPERATED BY SAVANNAH RIVER NUCLEAR SOLUTIONS

\title{
Characterization of Sample HTF-13-13-128
}

J. M. Pareizs

September 2013

SRNL-STI-2013-00513 
SRNL-STI-2013-00513

Revision 0

\section{DISCLAIMER}

This work was prepared under an agreement with and funded by the U.S. Government. Neither the U.S. Government or its employees, nor any of its contractors, subcontractors or their employees, makes any express or implied:

1. warranty or assumes any legal liability for the accuracy, completeness, or for the use or results of such use of any information, product, or process disclosed; or

2. representation that such use or results of such use would not infringe privately owned rights; or

3. endorsement or recommendation of any specifically identified commercial product, process, or service.

Any views and opinions of authors expressed in this work do not necessarily state or reflect those of the United States Government, or its contractors, or subcontractors.

\section{Printed in the United States of America \\ Prepared for U.S. Department of Energy}


SRNL-STI-2013-00513

Revision 0

Keywords: TANK FARM, TANK 13, SLUDGE BATCH 9

Retention: Permanent

\section{Characterization of Sample HTF-13-13-128}

J. M. Pareizs

September 2013

Prepared for the U.S. Department of Energy under contract number DE-AC09-08SR22470.

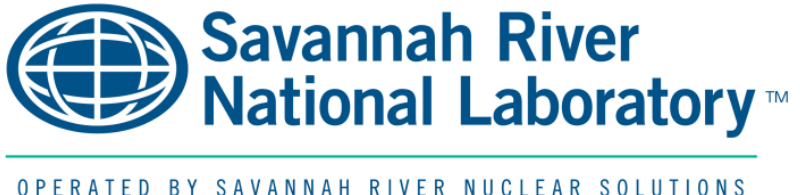




\section{REVIEWS AND APPROVALS}

AUTHORS:

J. M. Pareizs, Process Technology Programs

Date

TECHNICAL REVIEW:

M. S. Hay, Advanced Characterization and Processing, Reviewed per E7 2.60

Date

APPROVAL:

D. R. Click, Manager

Date

Process Technology Programs

S. L. Marra, Manager

Date

Environmental \& Chemical Process Technology Research Programs

E. J. Freed, Manager

Date

SRR Engineering 


\section{ACKNOWLEDGEMENTS}

The author would like to acknowledge the excellent support of the SRNL Shielded Cells technicians and management. The author would also like to acknowledge Michael Hay for the timely review of data to enable reporting of results via e-mail and memo as results became available. 


\section{EXECUTIVE SUMMARY}

Savannah River Remediation (SRR) has requested that Savannah River National Laboratory (SRNL) characterize a sample of Tank 13 in preparation for Sludge Batch 9 (SB9). A $200 \mathrm{~mL}$ sample of Tank 13 was received by SRNL on July 22, 2013 (Tank Farm sample ID HTF-13-13-128). Characterization of the sample to meet the requirements of the request is complete. Results include: visual observations; slurry and supernatant density; weight percent total and insoluble solids; supernatant characterization; total alpha, total beta, and several radionuclide analyses; and elemental analyses of the dried solids.

The sample was very fluid. After settling overnight, there was a small layer of solids on the bottom of the sample container (a $250 \mathrm{~mL}$ HDPE bottle) with the remainder being clear supernatant. To better show the sludge solids relative to the overall sample, $25 \mathrm{~mL}$ of slurry was placed in a graduated cylinder and allowed to settle over a weekend (approximately 90 hours). The sludge layer was at the approximately 4 $\mathrm{mL}$. The small visually observed quantity of insoluble solids was confirmed with a low weight percent insoluble solids of $0.94 \%$.

Based on analysis of this sample, SRNL recommends the following:

- Sulfur projections for SB9 should be based on ES analysis of supernatant and aqua regia-digested slurry, not on IC analysis. As with recent analyses, IC analysis of supernatant appears to only quantify approximately $80 \%$ of the total sulfur.

- SRNL should characterize a Tank 51 sample after all Tank 13 transfers. A Tank 51 sample would provide data for more accurate SB9 projections and reduce uncertainties in the amount of Tank 13 insoluble solids transferred to Tank 51. 


\section{TABLE OF CONTENTS}

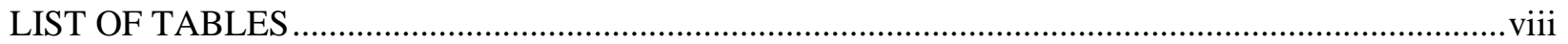

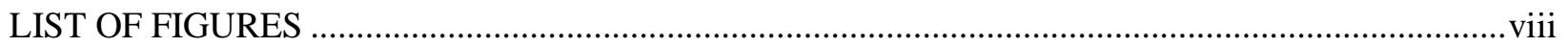

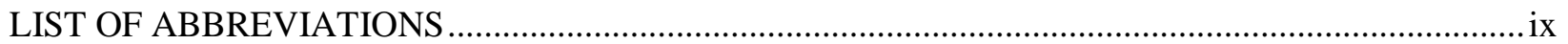

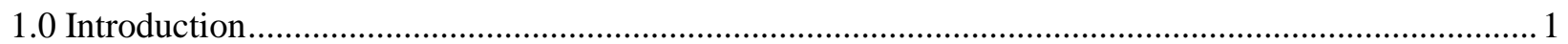

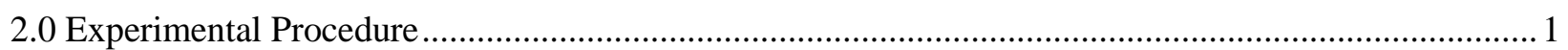

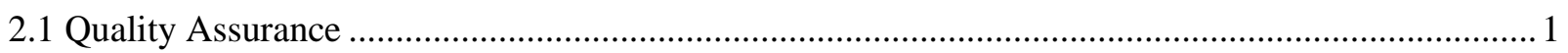

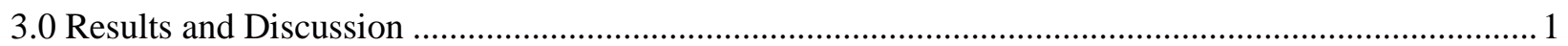

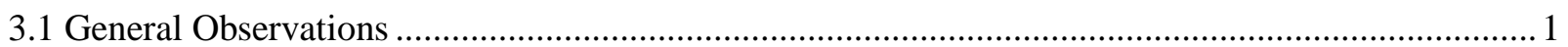

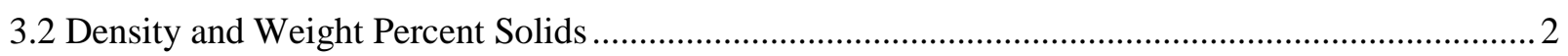

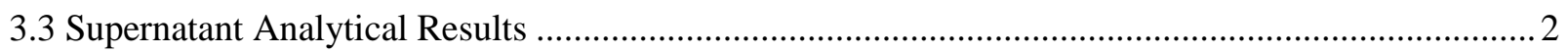

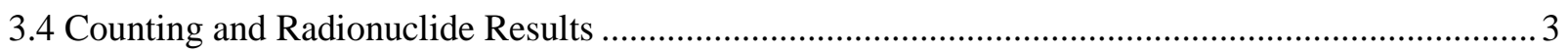

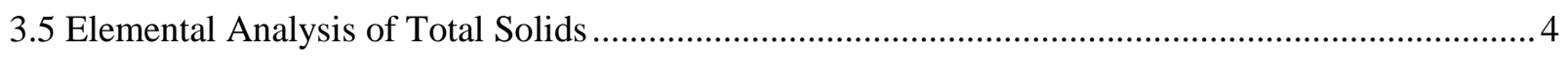

3.6 Calculation of Weight Percent Calcined Solids ..................................................................... 6

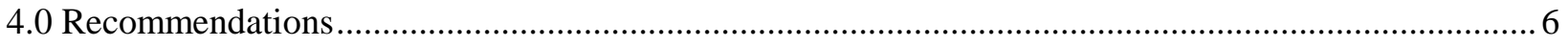

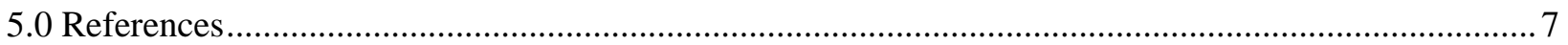




\section{LIST OF TABLES}

Table 3-1. Densities and Weight Percent Solids ..................................................................................... 2

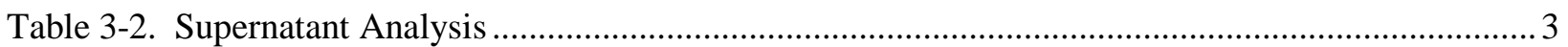

Table 3-3. Counting Results From Alkali Fusion Digestion of Slurry …................................................

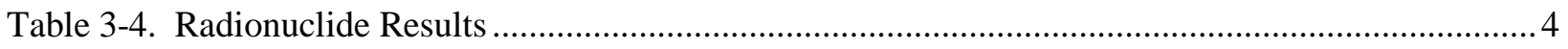

Table 3-5. Elemental Composition of Total (Dried) Solids ..................................................................... 5

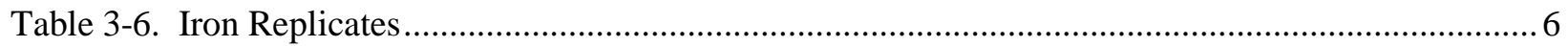

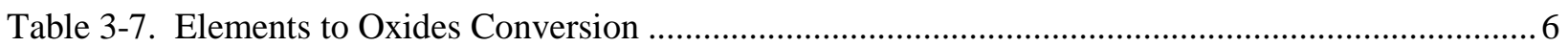

\section{LIST OF FIGURES}

Figure 3-1. Tank 13 Slurry After Settling 90 Hours............................................................................ 1 


\section{LIST OF ABBREVIATIONS}

$\begin{array}{ll}\text { AD } & \text { Analytical Development } \\ \text { AF } & \text { Alkali Fusion } \\ \text { AR } & \text { Aqua regia } \\ \text { ES } & \text { inductively coupled plasma-atomic emission spectroscopy } \\ \text { HDPE } & \text { high density polyethylene } \\ \text { IC } & \text { ion chromatography } \\ \text { ICP } & \text { Inductively Coupled Plasma } \\ \text { LSC } & \text { liquid scintillation counting } \\ \text { MS } & \text { inductively coupled plasma-mass spectroscopy } \\ \text { SB9 } & \text { Sludge Batch 9 } \\ \text { SRNL } & \text { Savannah River National Laboratory } \\ \text { SRR } & \text { Savannah River Remediation } \\ \text { TIC } & \text { Total inorganic carbon } \\ \text { Titr } & \text { Titration } \\ \text { TTR } & \text { Technical Task Request }\end{array}$




\subsection{Introduction}

Savannah River Remediation (SRR) has requested that Savannah River National Laboratory (SRNL) characterize a sample of Tank 13 in preparation for Sludge Batch 9 (SB9). ${ }^{1}$ A $200 \mathrm{~mL}$ sample of Tank 13 was received by SRNL on July 22, 2013 (Tank Farm sample ID HTF-13-13128). Characterization of the sample to meet the requirements of the request is complete.

This work is governed by a Task Technical and Quality Assurance Plan. ${ }^{2}$

\subsection{Experimental Procedure}

The as received Tank 13 sample was transferred from the Tank Farm sample bottle into a 250-mL high density polyethylene (HDPE) bottle. A subsample of the material was placed into a 25-mL graduated cylinder for a qualitative assessment of settling and insoluble solids quantity. To obtain supernatant, a portion of the slurry was filtered through a $0.45 \mu \mathrm{m}$ filter.

Slurry and supernatant densities were determined from sample weights in vessels of known volume. Slurry and supernatant aliquots were dried at $110{ }^{\circ} \mathrm{C}$ to a constant weight to obtain weight percent solids results. The dried slurry samples were heated to $1100{ }^{\circ} \mathrm{C}$, held at temperature two hours, cooled to ambient temperature, and weighed to determine weight percent calcined solids. Supernatant samples were diluted in the SRNL Shielded Cells (to reduce dose) and submitted to SRNL-Analytical Development (AD) for anion, elemental, and gamma analyses. Slurry samples were digested by both alkali fusion and aqua regia for elemental, radionuclide, and counting results. Specific digestion and analytical techniques are given with the results in the next section.

\subsection{Quality Assurance}

Requirements for performing reviews of technical reports and the extent of review are established in manual E7 2.60. SRNL documents the extent and type of review using the SRNL Technical Report Design Checklist contained in WSRC-IM-2002-00011, Rev. 2.

\subsection{Results and Discussion}

\subsection{General Observations}

The sample was very fluid. After settling overnight, there was a small layer of solids on the bottom of the sample container (a $250 \mathrm{~mL}$ HDPE bottle) with the remainder being clear supernatant. To better show the sludge solids relative to the overall sample, $25 \mathrm{~mL}$ of slurry was placed in a graduated cylinder and allowed to settle over a weekend (approximately 90 hours). A picture of the settled sample is given in Figure 3-1.

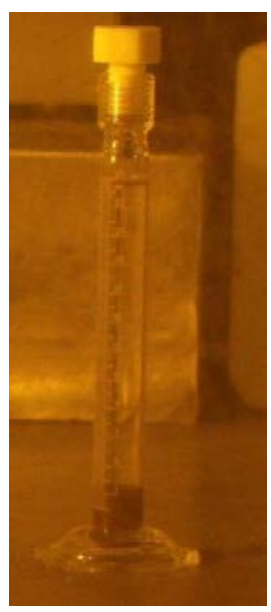

Figure 3-1. Tank 13 Slurry After 


\subsection{Density and Weight Percent Solids}

Presented in Table 3-1 are the density and weight percent solids results. Note that wt\% insoluble solids and soluble solids are calculated from the measured wt\% total and dissolved solids. As can be seen, the supernatant and slurry densities are virtually the same, which is consistent with the low wt\% insoluble solids.

A measurement of weight percent calcined solids was attempted twice. However, in both cases there was significant scatter. For example, in the second attempt, results ranged from $6 \%$ to $11 \%$, with an average of $9.7 \%$ and standard deviation of 3. A weight percent calcined solids of 13.7 wt\% (slurry basis) was calculated from elemental results and the measured weight percent total solids. See Section 3.6 for a discussion of the calculation and the assumptions used in the calculations. The scatter of results is likely due to the high salt content of the slurry. As the slurry was heated, the large quantity of anions may have caused splattering as they decomposed to gasses.

Table 3-1. Densities and Weight Percent Solids

\begin{tabular}{||c|c|c|}
\hline Property & Result & Std. Dev., n=4 \\
\hline $\begin{array}{c}\text { Slurry Density } \\
\text { (g/mL) }\end{array}$ & 1.210 & 0.005 \\
\hline $\begin{array}{c}\text { Supernatant Density } \\
\text { (g/mL) }\end{array}$ & 1.208 & 0.004 \\
\hline $\begin{array}{c}\text { Wt \% Total Solids } \\
\text { (Slurry Basis) }\end{array}$ & 23.41 & 0.02 \\
\hline $\begin{array}{c}\text { Wt \% Dissolved Solids } \\
\text { (supernatant basis) }\end{array}$ & 22.68 & 0.09 \\
\hline $\begin{array}{c}\text { Wt \% Insoluble Solids } \\
\text { (Slurry Basis) }\end{array}$ & 0.94 & NA \\
\hline $\begin{array}{c}\text { Wt \% Soluble Solids } \\
\text { (Slurry Basis) }\end{array}$ & 22.47 & NA \\
\hline
\end{tabular}

\subsection{Supernatant Analytical Results}

Presented in Table 3-2 are supernatant results. All supernatant analytes were determined from analysis of water-diluted filtrate (nominally 50X). The specific analytical technique for each analyte is given in the table.

As has been seen in recent samples, sulfate by ion chromatography (IC) is approximately $80 \%$ of the total sulfur as measured by inductively coupled plasma-atomic emission spectroscopy (ES). This difference is likely due to non-sulfate species in the sludge slurry. Therefore, it is recommended that sulfur be projected and tracked with sulfur via ES analyses for SB9. 
Table 3-2. Supernatant Analysis

\begin{tabular}{||l|c|c|c||}
\hline Analyte & Result & Std. Dev., $\mathbf{n = 4}$ & $\begin{array}{c}\text { Analytical } \\
\text { Method }\end{array}$ \\
\hline $\mathrm{Al}(\mathrm{M})$ & 0.414 & 0.005 & ES \\
\hline $\mathrm{C}_{2} \mathrm{O}_{4}{ }^{-}(\mathrm{M})$ & 0.0157 & 0.0002 & IC \\
\hline $\mathrm{CH}_{2} \mathrm{O}^{-}(\mathrm{M})$ & $<0.009$ & NA & IC \\
\hline $\mathrm{Cl}^{-}(\mathrm{M})$ & $<0.007$ & NA & IC \\
\hline $\mathrm{F}^{-}(\mathrm{M})$ & $<0.014$ & NA & IC \\
\hline $\mathrm{K}(\mathrm{M})^{\mathrm{NO}_{2}{ }^{-}(\mathrm{M})}$ & 0.0176 & 0.0003 & ES \\
\hline $\mathrm{NO}_{3}{ }^{-}(\mathrm{M})$ & 0.728 & 0.003 & IC \\
\hline $\mathrm{Na}^{(\mathrm{M})}$ & 0.989 & 0.003 & IC \\
\hline $\mathrm{PO}_{4}{ }^{3-}(\mathrm{M})$ & 4.23 & 0.05 & ES \\
\hline $\mathrm{S}(\mathrm{M})^{\mathrm{SO}}{ }^{2-}(\mathrm{M})$ & $<0.003$ & NA & IC \\
\hline $\mathrm{CO}_{3}{ }^{2-}(\mathrm{M})$ & 0.0707 & 0.0006 & ES \\
\hline Free OH (M) & 0.0571 & 0.0006 & IC \\
\hline $\mathrm{Cs}^{-137}(\mathrm{Ci} /$ gal sup.) & 0.18 & 0.03 & TIC \\
\hline
\end{tabular}

* ES=inductively coupled plasma-atomic emission spectroscopy; IC=ion chromatography; TIC=total inorganic carbon (carbonate is calculated assuming all inorganic carbon is carbonate); Titr.=titration: Counting=rad counting.

\subsection{Counting and Radionuclide Results}

Presented in Table 3-3 are liquid scintillation counting (LSC) and gamma scan results from alkali fusion digestions of slurry. Aliquots of slurry were dried and digested, followed by submission of the resulting liquids to AD for analysis. Total alpha and total beta were obtained from LSC. Cs137 was obtained from gamma scan.

Table 3-3. Counting Results From Alkali Fusion Digestion of Slurry

\begin{tabular}{|l|c|c|}
\hline \hline & $\begin{array}{c}\text { Result } \\
\text { (Ci/gal Slurry) }\end{array}$ & $\begin{array}{c}\text { Std. Dev., n=4 } \\
\text { (Ci/gal Slurry) }\end{array}$ \\
\hline Total Alpha & $<0.0072$ & NA \\
\hline Total Beta & 2.69 & 0.04 \\
\hline Cs-137 & 1.75 & 0.02 \\
\hline
\end{tabular}


Presented in Table 3-4 are radionuclide results. The digestion and analytical technique are given in the table.

Table 3-4. Radionuclide Results

\begin{tabular}{|l|c|c|c||}
\hline Radionuclide & $\begin{array}{c}\text { Result (Ci/g } \\
\text { Total Solids) }\end{array}$ & $\begin{array}{c}\text { Std. Dev., n=4 } \\
\text { (Ci/g Total } \\
\text { Solids) }\end{array}$ & $\begin{array}{c}\text { Dig, Analytical } \\
\text { Method }^{*}\end{array}$ \\
\hline U-233 & $<2 \mathrm{E}-08$ & NA & AR, MS \\
\hline U-235 & $6.4 \mathrm{E}-11$ & $4 \mathrm{E}-12$ & AR, MS \\
\hline U-236 & $<1 \mathrm{E}-10$ & NA & AR, MS \\
\hline U-238 & $1.37 \mathrm{E}-09$ & $3 \mathrm{E}-11$ & AR, MS \\
\hline $\mathrm{Pu}-238$ & $8.5 \mathrm{E}-06$ & $8 \mathrm{E}-07$ & PF, PU238/241 \\
\hline $\mathrm{Pu}-239$ & $1.6 \mathrm{E}-07$ & $2 \mathrm{E}-08$ & AR, MS \\
\hline $\mathrm{Pu}-240$ & $<5 \mathrm{E}-07$ & NA & AR, MS \\
\hline Pu-241 & $7.7 \mathrm{E}-07$ & $5 \mathrm{E}-08$ & PF, PU238/241 \\
\hline Am-241 & $2.9 \mathrm{E}-07$ & $2 \mathrm{E}-08$ & PF, AMCM \\
\hline $\mathrm{Am}-243$ & $2.2 \mathrm{E}-09$ & $2 \mathrm{E}-10$ & PF, AMCM \\
\hline $\mathrm{Am}-242 \mathrm{~m}$ & $3.0 \mathrm{E}-10$ & $3 \mathrm{E}-11$ & PF, AMCM \\
\hline $\mathrm{Cm}-243$ & $<5 \mathrm{E}-09$ & NA & PF, AMCM \\
\hline $\mathrm{Cm}-245$ & $<3 \mathrm{E}-09$ & NA & PF, AMCM \\
\hline $\mathrm{Cm}-247$ & $<2 \mathrm{E}-09$ & NA & PF, AMCM \\
\hline $\mathrm{Cf}-249$ & $<2 \mathrm{E}-09$ & NA & PF, AMCM \\
\hline $\mathrm{Cf}-251$ & $<1 \mathrm{E}-09$ & NA & PF, AMCM \\
\hline $\mathrm{Cm}-242$ & $2.5 \mathrm{E}-10$ & $2 \mathrm{E}-11$ & PF, AMCM \\
\hline $\mathrm{Cm}-244$ & $1.6 \mathrm{E}-07$ & $1 \mathrm{E}-08$ & PF, AMCM \\
\hline
\end{tabular}

* $\mathrm{AR}=$ aqua regia digestion; $\mathrm{AF}=$ alkali fusion digestion; MS=Inductively Coupled Plasma-MS; PU238/241=AD method with radiochemical separation and alpha pulse height analysis and liquid scintillation counting; AMCM=AD method with radiochemical separation and alpha and gamma pulse height analyses.

\subsection{Elemental Analysis of Total Solids}

Presented in Table 3-5 are elemental analyses of the total dried solids of the Tank 13 sample. Replicates, digestion method, and analytical method are also presented in the table. As requested in the Technical Task Request (TTR) ${ }^{1}$, all iron replicates are reported in Table 3-6. 
Table 3-5. Elemental Composition of Total (Dried) Solids

\begin{tabular}{|c|c|c|c|c|}
\hline Element & $\begin{array}{c}\text { wt } \% \text { of Total } \\
\text { Solids }\end{array}$ & $\begin{array}{l}\text { Std. Dev. } \\
\text { (wt\%) }\end{array}$ & Replicates & $\begin{array}{c}\text { Dig, Analytical } \\
\text { Method }^{*}\end{array}$ \\
\hline $\mathrm{Ag}$ & $<0.006$ & NA & NA & $\mathrm{AR}, \mathrm{ES}^{\dagger}$ \\
\hline $\mathrm{Al}$ & 4.76 & 0.06 & 8 & $\mathrm{AR} / \mathrm{AF}, \mathrm{ES}$ \\
\hline As & $<0.0006$ & NA & NA & AR, AA \\
\hline $\mathrm{B}$ & 0.0103 & 0.0007 & 4 & AR, ES \\
\hline $\mathrm{Ba}$ & 0.0035 & 0.0001 & 8 & AR/AF, ES \\
\hline $\mathrm{Be}$ & $<0.0004$ & NA & NA & AR, ES \\
\hline $\mathrm{Ca}$ & 0.059 & 0.002 & 4 & $\mathrm{AR}, \mathrm{ES}$ \\
\hline $\mathrm{Cd}$ & $<0.0005$ & NA & NA & AR, ES \\
\hline $\mathrm{Ce}$ & 0.0248 & 0.0006 & 4 & AR, ES \\
\hline $\mathrm{Cr}$ & 0.066 & 0.007 & 8 & $\mathrm{AR} / \mathrm{AF}, \mathrm{ES}$ \\
\hline Co & $<0.0009$ & NA & NA & AR, ES \\
\hline $\mathrm{Cu}$ & $0.0017^{\ddagger}$ & 0.0001 & 4 & AR, ES \\
\hline $\mathrm{Fe}$ & 1.79 & 0.05 & 8 & AR/AF, ES \\
\hline $\mathrm{Hg}$ & 0.40 & 0.01 & 4 & AR, CVHG \\
\hline $\mathrm{K}$ & 0.30 & 0.02 & 4 & AR, ES \\
\hline $\mathrm{La}$ & 0.00198 & 0.00008 & 4 & AR, ES \\
\hline $\mathrm{Li}$ & $<0.004$ & NA & NA & AR, ES \\
\hline $\mathrm{Mg}$ & 0.0083 & 0.0005 & 8 & AR/AF, ES \\
\hline $\mathrm{Mn}$ & 0.52 & 0.01 & 8 & $\mathrm{AR} / \mathrm{AF}, \mathrm{ES}$ \\
\hline $\mathrm{Na}$ & 32.6 & 0.5 & 4 & AR, ES \\
\hline $\mathrm{Ni}$ & 0.02915 & 0.001 & 4 & AR, ES \\
\hline $\mathrm{P}$ & 0.0419 & 0.0005 & 4 & AR, ES \\
\hline $\mathrm{Pb}$ & 0.0072 & 0.0005 & 4 & AR, ES \\
\hline $\mathrm{Pd}$ & ND & NA & NA & $\mathrm{AR}, \mathrm{MS}^{\dagger}$ \\
\hline $\mathrm{Rh}$ & 0.000695 & NA & NA & $\mathrm{AR}, \mathrm{MS}^{\dagger}$ \\
\hline $\mathrm{Ru}$ & 0.0022 & NA & NA & $\mathrm{AR}, \mathrm{MS}^{\dagger}$ \\
\hline $\mathrm{S}$ & 0.78 & 0.01 & 4 & AR, ES \\
\hline $\mathrm{Sb}$ & $<0.01$ & NA & NA & AR, ES \\
\hline Se & $<0.001$ & NA & NA & AR, AA \\
\hline $\mathrm{Si}$ & 0.086 & 0.002 & 4 & AF, ES \\
\hline $\mathrm{Ti}$ & $<0.003$ & NA & NA & $\mathrm{AF}, \mathrm{ES}$ \\
\hline Th & 0.050 & 0.005 & 8 & AR/AF, ES \\
\hline $\mathrm{U}$ & 0.37 & 0.02 & 8 & $\mathrm{AR} / \mathrm{AF}, \mathrm{ES}$ \\
\hline $\mathrm{Zn}$ & 0.0025 & 0.0001 & 4 & AR, ES \\
\hline $\mathrm{Zr}$ & 0.0092 & 0.0003 & 4 & AR, ES \\
\hline
\end{tabular}

* Dig, Analytical Method: AR=Aqua Regia; AF=Alkali Fusion; ES= ICP-ES; MS=ICP-MS; AA= Atomic Absorption

${ }^{\dagger}$ Typically Ag is determined from MS. However, masses used to calculate Ag were less than detectable. Therefore, the detection limit from ES was used. Pd, Rh, and Ru are calculated from MS. Masses used to calculate Pd were less than detectable.

${ }^{\ddagger} \mathrm{Cu}$ was detected in the blank; this result is likely biased high. 
SRNL-STI-2013-00513

Revision 0

Table 3-6. Iron Replicates

\begin{tabular}{|c|c|}
\hline $\begin{array}{c}\text { Iron from Alkali Fusion } \\
\text { (wt \% of Total Solids) }\end{array}$ & $\begin{array}{c}\text { Iron From Aqua Regia } \\
\text { (wt \% of Total Solids) }\end{array}$ \\
\hline 17.9 & 18.1 \\
17.4 & 18.2 \\
18.7 & 18.0 \\
17.9 & 17.1 \\
\hline
\end{tabular}

\subsection{Calculation of Weight Percent Calcined Solids}

As stated in Section 3.2, there was significant scatter in the weight percent calcined solids measurements (6.1\% to $11.9 \%)$. Therefore, a wt\% calcined solids was calculated from elemental results (Table 3-5) and the measured weight percent total solids (Table 3-1). First, the elements detected at greater than $0.5 \mathrm{wt} \%$ were converted to oxides and summed (see Table 3-7). In this calculation, it is assumed that these elements are converted to oxides and all anions such as nitrite, nitrate, and hydroxide are driven off in the calcining process. Therefore, this sum represents the mass of oxides (calcined solids) in $100 \mathrm{~g}$ of total dried solids. The sum was then used to calculate the wt\% calcined solids (slurry basis):

$\frac{58.1 \mathrm{~g} \text { oxides }}{100 \mathrm{~g} \text { total dried solids }} \times \frac{23.41 \mathrm{~g} \text { total dried solids }}{100 \mathrm{~g} \text { slurry }} \times 100=13.7 \%$

Table 3-7. Elements to Oxides Conversion

\begin{tabular}{|l|c|c|c|c||}
\hline Element & $\begin{array}{c}\text { wt\% of } \\
\text { Total } \\
\text { Solids }\end{array}$ & Oxide & $\begin{array}{c}\text { El. to } \\
\text { Oxide } \\
\text { Conv. }\end{array}$ & $\begin{array}{c}\text { Oxide } \\
\text { (wt\% } \\
\text { of total } \\
\text { solids) }\end{array}$ \\
\hline $\mathrm{Al}$ & 4.76 & $\mathrm{Al}_{2} \mathrm{O}_{3}$ & 1.889 & 8.99 \\
\hline $\mathrm{Fe}$ & 1.79 & $\mathrm{Fe}_{2} \mathrm{O}_{3}$ & 1.430 & 2.56 \\
\hline $\mathrm{Mn}$ & 0.52 & $\mathrm{MnO}$ & 1.291 & 0.67 \\
\hline $\mathrm{Na}$ & 32.6 & $\mathrm{Na}_{2} \mathrm{O}$ & 1.348 & 43.9 \\
\hline $\mathrm{S}$ & 0.78 & $\mathrm{SO}_{4}$ & 2.996 & 2.34 \\
\hline & \multicolumn{2}{|l}{} & Total & 58.51 \\
\hline
\end{tabular}

* The Element to Oxide Conversion factor (El. to Oxide Conv), also known as the gravimetric factor, is the ratio of the mass of the oxide to the mass of the element in that oxide.

\subsection{Recommendations}

Based on analysis of this sample, SRNL recommends the following:

- Sulfur projections for SB9 should be based on ES analysis of supernatant and aqua regiadigested slurry, not on IC analysis. As with recent analyses, IC analysis of supernatant appears to only quantify approximately $80 \%$ of the total sulfur.

- SRNL should characterize a Tank 51 sample after all Tank 13 transfers. A Tank 51 sample would provide data for more accurate SB9 projections and reduce uncertainties in the amount of Tank 13 insoluble solids transferred to Tank 51. 


\subsection{References}

1. Fellinger, T. L. Technical Task Request: Tank 13 and Tank 22 Analysis for Sludge Batch 9; Savannah River Site: Aiken, SC, 2013.

2. $\quad$ Pareizs, J. M.; Hay, M. S. Task Technical and Quality Assurance Plan for Tank 13 and Tank 22 Analyses for Sludge Batch 9; SRNL-RP-2013-00353; Savannah River National Laboratory: Aiken, SC, 2013. 


\section{Distribution:}

S. L. Marra, 773-A

T. B. Brown, 773-A

D. R. Click, 999-W

S. D. Fink, 773-A

C. C. Herman, 773-A

E. N. Hoffman, 999-W

F. M. Pennebaker, 773-42A

W. R. Wilmarth, 773-A

Records Administration (EDWS)

J. M. Bricker, 704-27S

T. L. Fellinger, 704-26S

E. J. Freed, 704-S

J. M. Gillam, 766-H

B. A. Hamm, 766-H

E. W. Holtzscheiter, 704-15S

J. F. Iaukea, 704-27S

D. W. McImoyle, 766-H

D. K. Peeler, 999-W

J. W. Ray, 704-S

P. J. Ryan, 704-30S

H. B. Shah, 766-H

D. C. Sherburne, 704-S

M. E. Stone, 999-W
D. J. Martin, 241-152H

A. W. Wiggins, 705-1C 